\title{
Peace through globalization and capitalism? Prospects of two liberal propositions
}

\author{
Journal of Peace Research \\ 2014, Vol. 51(2) 173-183 \\ (C) The Author(s) 2013 \\ Reprints and permission: \\ sagepub.co.uk/journalsPermissions.nav \\ DOI: $10.1177 / 0022343313497739$ \\ jpr.sagepub.com
}

@SAGE

\author{
Gerald Schneider \\ University of Konstanz
}

\begin{abstract}
The security externalities of globalization and capitalism continue to play an influential role in peace research. Typical contributions to these interrelated areas of scientific inquiry address the hope that the external openness (commercial liberalism) and the internal freedom of an economy (capitalist peace) pacify interstate as well as intrastate relations. I claim, despite the empirical support both theses have received, that they face considerable analytical hurdles. Commercial liberalism has, on a theoretical level, not yet moved much beyond the opportunity cost arguments that enlightenment philosophers first advanced more than 200 years ago. The capitalist peace research program similarly does not offer clear micro-level mechanisms explaining why the interactions between economic agents and political decisionmakers should be more peaceful in capitalist than in state-dominated economies. Drawing on the political economy literature, I argue that economic liberalism should distinguish between level- and change-effects of both globalization and capitalism and that thinking in analogies between domestic and interstate peace has prevented the field from making analytical headway. Both literatures will only profit from the advent of 'big data' in the case that the field addresses the theoretical challenges upfront.
\end{abstract}

\section{Keywords}

capitalist peace, commercial liberalism, economic interdependence, globalization

\section{Introduction}

The publication of the 50th anniversary issue of the Journal of Peace Research takes place in a year in which the world commemorates the centennial of World War I. Historians have attributed the 'Great War' with a highly diverse set of effects, ranging from the advent of 'total war' (Hobsbawm, 1993) over a growing cultural tolerance for 'mass killings' (Kramer, 2007) to the introduction of progressive taxation (Scheve \& Stasavage, 2010). Although some of these bold claims are disputed, there is little doubt that the mass carnage also heralded the definitive end to what has been described as the first era of global economic integration (Williamson, 2011). As is well known, World War I also infamously dashed the optimistic forecast of Angell's (1912) bold vision that the growing economic interdependence of the early 20th century made interstate wars futile. ${ }^{1}$

\footnotetext{
${ }^{1}$ Some historians have gone as far as conceiving of the outbreak of World War I as a malfunction of economic interdependence. Gartzke \& Lupu (2012: 148) reject this interpretation, arguing that the conflict 'did not begin among the interdependent powers'. See also Russett \& Oneal (2001: 174-177). Angell (1951: 151) had to defend himself against the misreading of his work according to which war would become 'impossible' as a consequence of growing economic interdependence: 'No one who had read the book could possibly believe that that was its meaning. Among the hundreds of reviews of the book at the time not one suggests this nonsense'.
}

Corresponding author:

gerald.schneider@uni-konstanz.de 
Interestingly, in its first decades of existence the Journal of Peace Research (JPR) neither reflected on Angell's core liberal thesis nor explored its intellectual twin, the capitalist peace proposition that Austrian economist Schumpeter (1918/19) had sketched at the end of World War I. On the contrary, the founding editor of the journal, Johan Galtung (1971: 107), in his classic 'A Structural Theory of Imperialism', advocated radical change as a means to overcome the 'structural violence' that the 'center' uses in its interactions with the 'periphery' of the international political system: 'redistribution by taking from the have's and giving to the have-not's is not enough: the structure has to be changed'. The organization of international trade is, according to Galtung's reinterpretation of the Hilferding-Luxemburg theory of imperialism, one of the core conflict-fostering features of the imperialist world economy.

It was only after the dissolution of the Soviet empire that contributions to JPR started to explore Angell's and Schumpeter's visions systematically. In 1996, editor Nils Petter Gleditsch decided to publish two empirical articles that shaped the study of the topic for the next decade in the same issue of the journal. ${ }^{2}$ While Oneal et al. (1996) proved to become one of the cornerstone publications within Russett \& Oneal's (2001; Oneal \& Russett, 1999) Kantian research program, Barbieri’s (1996) initial contribution to the field sparked a lively debate with dozens of research articles, some of them included in a special issue on the topic (Barbieri \& Schneider, 1999), and several replications of both Oneal et al. (1996) and Barbieri (1996, 2002). The dispute was finally settled in 2008 when Xiang, Xu \& Keteku (2007) demonstrated that Barbieri's rejection of what Nye (1988) had dubbed 'commercial liberalism' rested on the neglect to control for the power of the dyad members.

A second challenge to the traditional liberal research program and especially its core Democratic Peace proposition came from the literature on the Schumpeterian idea that capitalism makes states more peaceful (Weede, 1995; Mousseau, 2000; Schneider \& Gleditsch, 2010). Initial contributions to this literature saw the positive effect of a capitalist organization of the economy on the chance for interstate peace initially as a qualification of other liberal conjectures. Recent contributions by

\footnotetext{
2 The scientific literature on commercial liberalism started of course much earlier with significant empirical contributions by Rosecrance (1986), Russett (1967), and Wallensteen (1973) and a first formal model by Polachek (1980). For reviews of this literature, see among others Barbieri \& Schneider (1999), Mansfield \& Pollins (2003), and Schneider (2010).
}

Gartzke (2007) and Mousseau (2012, 2013; see also Mousseau et al., 2013), however, have extended the theoretical scope of this explanation, arguing that it supersedes the democratic peace. Unsurprisingly, this claim has found immediate criticism from Kantian peace scholars, most notably Dafoe (2011), Dafoe \& Russett (2013), and Dafoe, Oneal \& Russett (2013), who claim to have identified flaws in the research designs of Gartzke (2007), Mousseau (2013), and Mousseau et al. (2013).

While the debate over the capitalist peace thesis is not yet settled, it has, like the commercial liberalism proposition, also been transferred to the domestic realm. Both the civil capitalist peace and the domestic politics version of commercial liberalism have received considerable empirical support (Hegre, Gissinger \& Gleditsch, 2003; Bussmann, Schneider \& Wiesehomeier, 2005; Barbieri \& Reuveny, 2005; de Soysa \& Fjelde, 2010) while others have qualified the liberal optimism (e.g. Bussman $\&$ Schneider, 2007; Olzak, 2011).

As I have surveyed the literatures on commercial liberalism and the capitalist peace elsewhere recently (Schneider, 2010; Schneider \& Gleditsch, 2010; Schneider, 2013), I will mainly emphasize the theoretical and empirical challenges that the two interlinked literatures face. My essay first contends that the two arguments should be seen as complements rather than as competing explanations and that capitalism and globalization necessitate each other. As the literatures on the capitalist peace and commercial liberalism explicitly or implicitly resort to opportunity cost arguments or macro-sociological reasoning, they need more solid micro-foundations and a sounder footing in the political economy literature.

I specifically contend, in line with the redistributive interpretation of commercial liberalism introduced by Bussmann \& Schneider (2007), that the effects of liberal policies on social cohesion need to be taken into account and that we should distinguish between the intensity of economic liberty domestically (capitalism) and internationally (globalization) as well as the changes made in these levels. A classification of the redistributive effects that I introduce identifies in line with recent theoretical work how different parts of the society react to an external or internal liberalization of the economy and how this might affect the risk of both interstate and civil war. Although progress in both research areas covered here ultimately has to come from sounder theoretical reasoning, this essay also positively discusses the usage of network analysis and event data. I argue in particular that the field should try to profit from the arrival of 'big data' (e.g. King, 2011) to study the interactions between the economy and the incentives to employ political violence, 
but that this development needs to be accompanied by equivalent theoretical progress.

\section{Complements rather than competitors: The theoretical status of the liberal twins}

Both economic globalization and capitalism share the fate that the different ideologies attribute radically opposing effects to them. Marxist and Leninist scholars have advocated for more than 150 years that the capitalist organization of the economy and its inherent need to globalize national markets is the root cause of modern social conflict. Liberals, by contrast, expect that economic liberty and some of its key features, trade and capital account openness, as well as the ease with which private contracts can be concluded, are major sources of peace. These conflicting interpretations of the benefits and ills of globalization and capitalism render it necessary to define clearly how the two notions can be separated theoretically from each other and what kind of effects they are supposed to have on the risk of conflict.

To start with, I agree with McDonald (2009) that we can clearly differentiate between the capitalist and the globalization variants of the liberal peace on a conceptual level, although they are closely interlinked empirically. In his view, state ownership yields governments the financial autonomy to pursue aggressive policies. Protectionism, conversely, similarly enables a militaristic executive to trade the protectionist rents reaped by the importcompeting sector for its support of an aggressive foreign policy the government wishes to pursue. This definition has the advantage that it sees economic integration and a capitalist orientation as the opposite sides of the same coin, standing for the freedom of commerce externally and internally, respectively.

The intellectual fathers of the two liberal peace propositions, Norman Angell and Joseph Alois Schumpeter, defined their core concepts in a similar fashion. Alluding to the German arms buildup and the fears accompanying it, Angell (1912: 27-28) speaks of the 'delicate interdepence' of the war-affected economies and maintains that an invasion would 'make the damage to the invader resulting from the confiscation exceed in value the property confiscated. So that Germany's success in conquest would be a demonstration of the complete economic futility of

\footnotetext{
${ }^{3}$ One chapter in Angell's (1951) memoirs, tellingly entitled 'The Story of a Pamphlet', recasts the difficult origins of the initial treatise (Europe's Optical Illusion, 1908) which was expanded into the bestseller The Great Illusion (first published in November 1909, first new edition November 1910).
}

conquest.' ${ }^{3}$ In the wake of World War I, Schumpeter (1918/19) developed in contrast to Angell a purely domestic-level explanation of war that considers imperialism and nationalism as drivers of agression. While imperialism is, in his view, 'the objectless disposition of a state to expand violently' (p. 3, own translation), nationalism consists of a 'consciousness of the national peculiarity plus an aggressive feeling of manly predominance' (p. 143, own translation).

Differentiating between the interdependence and capitalist peace literatures in the footsteps of Angell and Schumpeter as distinct but interrelated phenomena implies two distinct measurement strategies. First, we can approximate the global economic integration of a country through its trade and capital account openness. Second, the economic freedom that the domestic agents enjoy in dealing with each other can, on the other hand, serve as a proxy for the capitalist structure of the economy. While empirical studies of commercial liberalism have mainly focused on trade and foreign direct investment as indicators of the external openness of the economy, the capitalist peace literature has not yet come up with a standard set of measures. This is most likely a consequence of the tendency of some scholars to define capitalism very broadly and, at least implicitly, in a functionalist manner. This wide-stretched operationalization of the capitalist peace characterizes for instance Mousseau's (2000) 'economic norms theory' which initially used economic development and currently relies on the contract intensity of a country to measure how much the capitalist 'norms' have gained ground within a society. Distinguishing between a Hayekian and a Keynesian version of capitalism, Mousseau et al. (2013: 81) have argued recently that the government-enforced contracting of economic agents with each other 'creates a direct interest in the health and welfare of everyone else in the market', rendering 'war, both within and among capitalist nations, virtually unthinkable'.

The optimistic expectation of Mousseau et al. (2013; Mousseau, Orsun \& Ungerer, 2013) resembles Angell's (1912) vision of the peaceful effects of interdependence, according to which war is pointless as the benefits accruing from economic activities outweigh the utility of using

\footnotetext{
${ }^{4}$ Note that Mousseau et al. (2013) call the Hayekian model 'market' capitalism and the Keynesian model 'social market capitalism'. This dichotomous definition is, however, partially misleading as Hayek supported the introduction of a market economy advocated by some of his fellow ordo-liberals under the banner 'Soziale Marktwirtschaft', which can be translated as 'social market economy', although he questioned the usefulness of adding the adjective 'social' (see Barry (1993) for an idea history of these notions in Germanspeaking Europe).
} 
political force. The continuing popularity of invoking opportunity cost arguments and macro-level reasoning in support of the liberal theses becomes visible for instance in Oneal \& Russett's (1999: 5) early formulation of the Kantian research program: 'Fearful of the domestic political consequences of losing the benefits of trade, policymakers avoid the use of force against states with which they engage in economically important trade." Nieman (2011: 282) similarly argues that 'globalization decreases internal violence by raising opportunity costs of joining an insurgency group'.

Even though the opportunity cost argument underlying most contributions to commercial liberalism and the capitalist peace is straightforward, it does not, in my view, offer a convincing causal mechanism (Schneider, 2010; Schneider \& Gleditsch, 2010). To start with, I argue in line with Fearon (2008) that the effect of a growing economy on the individual propensity to rely on force is indeterminate: while the increased rents that capitalism and economic interdependence create make the usage of political violence more attractive, they also increase the chance that a potential foe might find employment in the regular economy. The argument lacks also, at least with regard to international conflict, a clearly specified aggregation mechanism that would allow us to understand how diverging social preferences at the domestic level translate into aggressive foreign policies at the national level. ${ }^{6}$

A second and more fundamental analytical problem of the opportunity cost argument is, in my view, its lack of motivation for both economic activities and war, rendering the causal argument almost tautological. Because it postulates that increasing economic integration or growing welfare due to the absence of stifling market interventions diminishes the attractiveness of using political violence, becoming more aggressive in the interaction with another state or a competing internal group is an irrational act by definition. Hence, if we assume that closing an economy to foreign competition and

\footnotetext{
${ }^{5}$ Russett \& Oneal (2001: 130) have added a domestic politics component to this line of reasoning: 'If maintaining trade is important to continuing national prosperity and growth, leaders will be responsive to its beneficiaries.'

${ }^{6}$ An earlier criticism of the opportunity cost argument is due to Gartzke, Li \& Boehmer (2001); for a critique of their specific rejection of this line of reasoning see Polachek \& Xiang (2010). Gartzke, Li \& Boehmer (2001) specifically advance a strategic version of commercial liberalism, but their model does not involve economic agents explicitly. For a similar discussion of the problems of developing 'realist' models of commercial liberalism, see Morrow (1999).
}

decreasing the chance for free economic activities are costly acts, we 'explain' both commercial liberalism and the capitalist peace through this (plausible) assumption and not through moves made by actors in a political game. Third and finally, most opportunity cost arguments are formulated at the state level and therefore implicitly assume that the effects of capitalism and economic interdependence are uniform across the different social groups or that at least the redistributive effects of external and internal openness are negligible. This analytic artifice has the advantage that states can be conceived as unitary actors or, to put it more historically, as mercantilist do-gooders which are only interested in the maximization of social welfare. However, if we want to understand why states open up their economies internally or externally and what sort of security effects these reforms have, we have to understand the relationship between the state and relevant economic and social actors (Schneider \& Schulze, 2003; Simmons, 2003). ${ }^{7}$

We need, in other words, to shift to an instrumental interpretation of war and other forms of political violence and explain the conditions under which governments and political groups use force and employ liberal economic policies or rather opt for the contrary choices. Liberal explanations of peace and war therefore have to explain cooperative and conflictive moves alike and not assume either of them away. This will, in my view, only become possible if we carefully think about the profiteers of economic openness and, consequently, if we move away from the mercantilist perspective that goes hand in hand with the usage of many explicit or implicit opportunity cost arguments or macro-sociological analogies. ${ }^{8}$

\section{Linking capitalism and globalization to war and peace}

Most economists agree that openness and free markets stimulate, at least to a certain extent, economic

\footnotetext{
${ }^{7}$ Gelpi \& Grieco (2008) similarly argue that the positive effect of economic interdependence necessarily hinges on the presence of democratic institutions.

${ }^{8}$ Using a standard neo-classic model of trade policymaking, Polachek (1980) assumed in his classic treatise that governments will behave as social-welfare maximizers. This simplification allowed him to show that the demand for an aggressive foreign policy course should go down when a state intensifies its commercial ties with another nation. In other words, he implicitly expects governments to take the opportunity costs into account that harmful foreign policy decisions create. In the neo-classical perspective, the risk of interstate war should thus unconditionally decrease if a state embarks on a course of foreign economic liberalization.
} 
development (Frey et al., 1984). Subramanian \& Wei (2007) for instance provide compelling evidence that the additional openness associated with becoming a member of the World Trade Organization increases growth, while Sadeh (2013) demonstrates that the European Monetary Union stimulated trade, and Alesina et al. (2005) show that deregulation of domestic markets spurs growth as it facilities entry into closed markets and attracts subsequent investment of the new competitors. However, these positive level-effects stand in contrast to the adjustment costs that both an external and internal liberalization cause. Commercial liberalism and the capitalist peace literature do not, in other words, sufficiently consider that changing levels of external and internal economic openness might endanger the liberal economic peace envisioned by Angell (1912), Schumpeter (1918/ 19), and other eminent thinkers.

Standard political economy models help us to identify the winners and losers of these political changes and how these anticipated and realized redistributions influence their attitude towards a domestic revolt or a government's decision to use force against another state. In the following, I will analyze trade and capital account liberalization as well as how domestic deregulation might influence the potential for political violence abroad and at home.

\section{Trade liberalization}

Two theoretical traditions in trade theory - the Heckscher-Ohlin and the Ricardo-Viner models - are the canonical starting point to understand the redistributive effects of trade liberalization. The former approach sees the main cleavage in trade policymaking between owners of different factors, while the latter focuses on the division between the export and the import-competing industry. ${ }^{9}$ The Ricardo-Viner framework of analysis becomes valid for the study of conflict through its assumption that certain factors remain 'specific' for a certain industry, at least in the short run, as capital and labor cannot easily move to a more profitable sector following a reduction in the tariff level or another similarly liberalizing step being taken. Melitz (2003) adds to this the observation that firms are not homogeneous. We can expect in this vein that workers in the less productive

\footnotetext{
${ }^{9}$ McDonald (2009) identifies in his work on commercial liberalism and the capitalist peace the import-competing sector as the main profiteer from protectionism, but does not motivate the preference of the government for aggressiveness through a political economy framework.
}

firms will be particularly opposed to liberalizing measures. In the perspective of the Heckscher-Ohlin model finally, the winners of trade liberalization are high-skilled individuals and those who belong to the abundant factor within an economy - capital in the developed, labor in the developing world. Spilerman (2009: 77) identifies along these lines the profiteers and losers of globalization, stating that 'in the developed world, the relative positions of capital and labour have shifted, with capital the clear winner'. The growing inequality that has gone hand in hand with increased economic interdependence is especially pronounced in the United States (Massey, 2009), but it is also one of the key reasons for the delayed but growing income disparities among other developed nations such as Germany (Dustmann, Ludsteck \& Schönberg, 2009). If economic interdependence continues to grow, labor might, however, catch up, at least a bit. According to Acemoglu, Gancia \& Zilibotti (2012), the skill premium could be lowered to the benefit of unskilled workers once offshoring reaches a critical level. Be that as it may, the growing economic interdependence has also widened the middle class in some developing countries and emerging economies so that the global income inequality has, at least according to the calculations of Sala-i-Martin (2006), diminished rather than expanded.

Irrespective of these disputed trends, we can expect that the risk of internal conflict increases during the period that a country embraces or at least disputes the liberal recommendation of slashing tariffs or other barriers to trade and commerce. While Bussmann \& Schneider (2007) expect the risk of violence to grow in the liberalizing years, Magee \& Massoud (2011) identify the turning point some years before a country satisfies the Sachs \& Warner (1995) openness conditions. The conditions under which increasing trade liberalization might increase the risk of conflict are more involved. Schneider \& Schulze (2003) consider the tax base effect of globalization in a price-taking (i.e. small) economy where three groups - the military, the import-competing, and the export-sectors - evaluate the foreign and trade policies of the government. Their extension of the RiccardoViner framework to a third sector shows that growing trade can go hand in hand with more aggressive foreign policy as long as the marginal benefits of growing trade openness outweigh the marginal costs of hostile interaction with other states. The analysis implies that countries might have unilateral incentives to become more aggressive in times of increased globalization. This constellation, however, only lasts as long as the government has to pay attention to a military that is interested in a 
growing tax base and, as a consequence of this globalization effect, potentially larger defense budgets.

If we compare these political economy qualifications of the 'peace through trade' hypothesis, the limitations of drawing analogies between internal and international war become apparent. While the former sort of armed violence juxtaposes the government against a group of globalizations losers, the risk of interstate war in times of increasing economic bonds only increases if the government crucially depends on the support of the military and, up to a certain level, the export sector.

The theoretical model underlying commercial liberalism also becomes more complicated if we disaggregate the nature of the traded goods. Dorussen's (2006) dyad-level analysis offers encompassing evidence that the positive relationship of globalization is weaker for trade in chemicals or high-technology products, as well as in commodities that are more easily appropriable by force. Goenner (2010) likewise demonstrates the benefits of disaggregation and warns that the risk of bilateral conflict might increase in response to an increasing share of trade in metals in comparison to a stagnant trade in non-strategic products.

Trade in natural resources, especially oil, might also increase the risk of interstate (Colgan, 2010) and civil war (Ross, 2012). ${ }^{10}$ There are obviously several potential arguments that can be made in support of such empirical regularities. Garfinkel, Skaperdas \& Syropoulos (2008: 307) develop a pertaining political economy argument of the domestic 'resource curse' that considers the international market price of a domestically contested and exportable resource: 'Although for importers of oil and other natural resources opening up the economy brings the regular benefits of trade and reductions in conflict, for exporters of the same resources opening the economy to trade can very well induce increased conflict costs that more than offset the familiar gains from trade.' This suggests more broadly that commercial liberalism needs to consider the price of the traded resources and the effects that trade liberalization has on the income of relevant actors and their inclination to use force in the internal affairs of the state or to support aggressive foreign policies of the government.

\section{Capital account liberalization and deregulation}

The theoretical literature of how capital account liberalization and the deregulation of domestic markets affect the

\footnotetext{
${ }^{10}$ Ross (2012) relies on oil income per capita as an indicator of what he calls the 'oil curse', while Colgan (2010) similarly defines countries as 'petrostates' if net oil exports per year amount to at least $10 \%$ of the annual GDP.
}

risk of domestic and international conflict is not as well developed as the literature on trade liberalization. We can, however, assume that openness on these fronts renders a country more attractive for foreign investors. Liberal scholars frequently invoke a rational expectations argument to explain why the capital inflow resulting from increasing internal and external openness should appease a country domestically and internationally. According to their adage, investors will refrain from investing in a country that they consider to be too risky. Although this reasoning already suggests that FDI is endogenous to the factors that stabilize a country in the first place, the studies published in support of this facet of the globalization thesis do not control for it (DiGiuseppe, Barry \& Frank, 2012; Bussmann, 2010; Bussmann \& Schneider, 2007).

A second pacifying effect of investment is due to the development stimulus that has been a key feature in almost all theories of economic growth. This makes it reasonable to assume, in line with Alesina et al. (2005), that deregulation will at least in the long run increase collective welfare. However, globalization critics maintain that capital account liberalization and deregulation are not as innocuous. Arestis \& Caner (2010: 321) show for instance that 'capital account openness is associated with a lower income share of the poorest $20 \%$ of the population'. Furthermore, especially Stiglitz (2000, 2002, 2004) maintains in his popular and scientific writing that the short-term investment inflows that might follow a capital account liberalization can destabilize societies. In his view, 'capital flows are markedly procyclical, exacerbating economic fluctuations, when they do not actually cause them' (Stiglitz, 2000: 1079). If a liberalized economy loses the trust of the international financial community during a crisis and is confronted with a radical outflow of short-term investments, social unrest might be a likely outcome. Deregulation might equally destabilize societies. Hartzell, Hoddie \& Bauer (2010: 353) find a positive impact of the entry into structural adjustment programs and argue that 'the IMF-guided process of liberalization generates new losers at a rate with which a state with weakening powers is incapable of contending'. Midtgård, Vadlamannati \& de Soysa (2013), however, show that slight changes in the research design lead to completely different findings and that IMF programs might at least reduce the risk of lower-scale conflicts.

\section{Why we need more theory and better, not necessarily more data}

The typical research design for the academic study of the capitalist peace and the 'peace through globalization' 
theses has for a long time relied on the dyad or countryyear as units of analysis. It took the import of network analysis to conflict research and some other methodological advances to recognize that the 'data generating process' is most often multilateral, at least for tests of the interstate version of commercial liberalism. According to Poast (2010: 422): 'empirical scholars have widely used data suggesting otherwise: when analyzing multilateral events, they often divide the actors involved into a series of dyadic relations, thereby creating observations that disregard the dyad's relations with outside actors'. This means that statistical models which do not take the multilateral nature of international trade (and also often of international conflict) into account are most likely always misspecified.

Theoretically, dyadic or country-year tests of the globalization thesis have to resort to the highly unrealistic assumption that the trade of country A with country B cannot easily be replaced by trade with another country in case a political conflict arises. Obviously, such a bilateral interpretation of world trade contradicts the insight by Ricardo and other classic political economists that trade relationships are substitutable in a globalized world at least in the medium term. The multilateral nature of international trade also holds for unequal dyads as large states can easily disregard the commercial losses that the breakup of a trading relationship with a small partner brings about as they are able to redirect their trade to customers elsewhere. Small countries can, conversely, also search for trading partners elsewhere in the event that the relationship with large trading partner sours. The only limitation to my argument that trading partners can be exchanged and that a multilateral framework is more appropriate than a monadic or dyadic one is in considering the relationship between large countries or trading blocks. These exceptions are at the moment possibly the interactions between the European Union, the People's Republic of China, and the United States. ${ }^{11}$

It should be noted that neglecting to consider the multilateral nature of trade does not condemn the liberal research agenda to the dustbin. On the contrary, network analyses of commercial liberalism political economy research have mainly confirmed the liberal hope that increasing economic interdependence pacifies states (e.g. Maoz, 2009; Dorussen \& Ward, 2010;

\footnotetext{
${ }^{11}$ The argument developed in this paragraph draws on unpublished work of the author with Günther Schulze.
}

Kinne, 2012). ${ }^{12}$ Similarly, studies of domestic deregulation and the capitalist peace need to take the temporal and spatial dynamics into account as such reforms are influenced by recent policy choices in other states and the ups and downs of liberalism as a political ideology. Most studies consider these transnational influences (e.g. Simmons \& Elkins, 2004).

The need to adjust the research designs for the specific nature of commercial and political relationships also holds for the capitalist peace and the domestic variant of commercial liberalism. This is especially the case in socially or ethnically fragmented countries that embark on a course of internal or external liberalization. Olzak (2011: 21, italics suppressed) demonstrates empirically that diversity might intensify the violence stemming from economic integration: 'economic globalization actually raises the rate of fatalities from ethnic civil war'. Wiesehomeier, Schneider \& Braun (2009), conversely, consider different forms of diversity, demonstrating that the interaction of both fractionalization and polarization with liberalization reduces the risk of civil war. Be that as it may, the arrival of disaggregated information on the income levels of ethnic groups will allow more precise testing of whether the effects of globalization on inequality fuel or dampen the risk of internal instability. In order to do so, researchers have to differentiate between the income and redistributive effects that liberalization has even for the less privileged group. The former impact might dwarf the latter so that increased globalization remains relatively uncontroversial. Empirically, this suggests that the study of the liberalization-conflict nexus moves below the country-year framework. Surveys (e.g. Østby, 2008) or GIS-data (e.g. Cederman, Weidmann \& Gleditsch, 2011) might be possible data resources for the future analysis of the impact that globalization and capitalism might have on the internal stability of states.

The arrival of 'big data' in the social sciences (e.g. King, 2011) will without doubt revolutionize the study of the liberal theses in the near future. I particularly believe that the renaissance of event data in conflict research (Schrodt, 2012) holds particular promise in this research field as it allows conflict researchers to study the

\footnotetext{
${ }^{12}$ Note that commercial liberalism has also re-emerged strengthened from the challenge posed by Keshk, Pollins \& Reuveny's (2004) simultaneous equation model showing that bilateral trade does not reduce the risk of conflict, while militarized interstate disputes decrease trade. Hegre, Oneal \& Russett (2010) and Goenner (2011) resurrect the liberal hope in replications and extensions of the Keshk, Pollins \& Reuveny statistical model.
} 
interactions between politics and economics at a much lower level of temporal and, possibly, spatial aggregation (e.g. Schneider \& Troeger, 2006). Quite trivially, if we assume economic decisions to affect politics and vice versa in the long run, as the political economy literature of violent conflict has done for decades, it should be much easier to observe economic and political reactions to them in the short run.

However, the arrival of new data sources will only have a lasting impact if the proponents of the liberal theses are also willing to work hard in the theoretical identification of the situations under which commercial liberalism and the capitalist peace work and in which contexts the arguments need to be qualified. Hence, the main challenges to the liberal propositions reviewed in this article are of a theoretical rather than methodological nature despite the calls for instrumental variable approaches by Martin, Mayer \& Thoenig (2008), Magee $\&$ Massoud (2011), and others, simultaneous equation models (e.g. Keshk, Pollins \& Reuveny, 2004) and, as discussed, network models (e.g. Poast, 2010). Although we may be able to tackle endogeneity bias and other problems through the application of advanced econometric techniques, their presence surely signals the need for further theoretical reasoning in the liberal research program.

\section{Conclusion}

The end of the Cold War has spurred the liberal hope that economic openness and economic freedom will make the world more peaceful. Even the advent of murderous transnational terrorist movements like Al-Qaeda has not much shattered the 'liberal moment' according to which the world has become a safer place (Gleditsch, 2008). However, the financial and economic crisis that a politically protected financial sector has brought over the developed world has wrecked two key liberal ideas - globalization and capitalism - to such an extent that political theorists only dare to employ them with prefixes like 'after' or 'post' (e.g. Cazdyn \& Szeman, 2011; Schweickart, 2011). The anti-globalization and anti-capitalism that we are currently witnessing should, however, not deter conflict researchers from carefully examining the claims of Angell (1912) and Schumpeter (1918/19) that both economic interdependence and economic freedom are major forces of peace.

I have in this article advanced the position that we need to qualify these hopes and to explore both the pacifying effect of economic integration and economic freedom and the potentially disruptive consequences of the accompanying liberalization measures. Although external and internal deregulation is inevitably contentious, at least in the short run, not even the severest big bang reforms need to lead to political violence as the losers of pro-globalization and pro-capitalism reforms will have the possibility to voice their protests differently in politically open regimes. Hence, peace research needs to realize that political violence is often the instrument of last resort and that actors will generally prefer to invest in 'cheaper' forms of protest to articulate their anger over a planned liberalization (Schneider, 2013).

The recognition that the way towards a safer, freer, and more integrated world will be contested implies for peace and conflict researchers the need to pay attention to the way in which liberalizing measures are implemented and whether the losers of globalization and capitalism are compensated in one way or another. Interestingly, liberal researchers have only rarely examined how different facets of the liberal research program condition each other. Although governments might need to implement liberalizing economic reforms, this might not necessarily translate into a more conflictual world.

\section{Acknowledgements}

I would like to thank Allan Dafoe, Nils Petter Gleditsch, Michael Mousseau, John Oneal, Paul Poast, Constantin Ruhe, Bruce Russett, the anniversary issue editors, and three reviewers for helpful discussions or comments, Rosie Gant for research assistance, and the German Research Foundation for research support.

\section{References}

Acemoglu, Daron; Gino Gancia \& Fabrizio Zilibotti (2012) Offshoring and directed technical change. NBER working paper no. 18595 (http://www.nber.org/papers/w18595).

Alesina, Alberto; Silvia Ardagna, Giuseppe Nicoletti \& Fabio Schiantarelli (2005) Regulation and investment. Journal of the European Economic Association 3(4): 791-825.

Angell, Norman (1912) The Great Illusion: A Study of the Relation of Military Power in Nations to Their Economic and Social Advantage. London: Heinemann.

Angell, Norman (1951) After All. London: Hamish Hamilton.

Arestis, Philip \& Asena Caner (2010) Capital account liberalization and poverty: How close is the link? Cambridge Journal of Economics 34(2): 295-323.

Barbieri, Katherine (1996) Economic interdependence: A path to peace or a source of international conflict? Journal of Peace Research 33(1): 29-49. 
Barbieri, Katherine (2002) The Liberal Illusion: Does Trade Promote Peace? Ann Arbor, MI: University of Michigan Press.

Barbieri, Katherine \& Rafael Reuveny (2005) Economic globalization and civil war. Journal of Politics 67(4): 1228-1247.

Barbieri, Katherine \& Gerald Schneider (1999) Globalization and peace: Assessing new directions in the study of trade and conflict. Journal of Peace Research 36(4): 387-404.

Barry, Norman (1993) The social market economy. Social Philosophy and Policy 10(2): 1-25.

Bussmann, Margit (2010) Foreign direct investment and militarized international conflict. Journal of Peace Research 47(2): 143-153.

Bussmann, Margit \& Gerald Schneider (2007) When globalization discontent turns violent: Foreign economic liberalization and internal war. International Studies Quarterly 51(1): 79-97.

Bussmann, Margit; Gerald Schneider \& Nina Wiesehomeier (2005) Foreign economic liberalization and peace: The case of sub-Saharan Africa. European Journal of International Relations 11(4): 551-579.

Cazdyn, Eric \& Imre Szeman (2011) After Globalization. Chichester: John Wiley \& Sons.

Cederman, Lars-Erik; Nils B Weidmann \& Kristian Skrede Gleditsch (2011) Horizontal inequalities and ethnonationalist civil war: A global comparison. American Political Science Review 105(3): 478-495.

Colgan, Jeffrey (2010) Oil and revolutionary governments: Fuel for international conflict. International Organization 64(4): 661-694.

Dafoe, Allan (2011) Statistical critiques of the democratic peace: Caveat emptor. American Journal of Political Science 55(2): 247-262.

Dafoe, Allan \& Bruce Russett (2013) Does capitalism account for the democratic peace? The evidence still says no. In: Gerald Schneider \& Nils Petter Gleditsch (eds) Assessing the Capitalist Peace. Abingdon: Routledge, 110-126.

Dafoe, Allan; John R Oneal \& Bruce Russett (2013) The democratic peace: Weighing the evidence and cautious inference. International Studies Quarterly 57(1): 201-214.

de Soysa; Indra \& Hanne Fjelde (2010) Is the hidden hand an iron fist? Capitalism and civil peace, 1970-2005. Journal of Peace Research 47(3): 287-298.

DiGiuseppe, Matthew R; Colin M Barry \& Richard W Frank (2012) Good for the money? International finance, state capacity and internal armed conflict. Journal of Peace Research 49(3): 391-405.

Dorussen, Han (2006) Heterogeneous trade interests and conflict: What you trade matters. Journal of Conflict Resolution 50(1): 87-107.

Dorussen, Han \& Hugh Ward (2010) Trade networks and the Kantian peace. Journal of Peace Research 47(1): 29-42.

Dustmann, Christian; Johannes Ludsteck \& Uta Schönberg (2009) Revisiting the German wage structure.Quarterly Journal of Economics 124(2): 843-881.
Fearon, James D (2008) Economic development, insurgency, and civil war. In: Elhanan Helpman (ed.) Institutions and Economic Performance. Cambridge, MA: Harvard University Press, 292-328.

Frey, Bruno S; Werner W Pommerehne, Friedrich Schneider \& Guy Gilbert (1984) Consensus and dissension among economists: An empirical enquiry. American Economic Review 74(5): 986-994.

Galtung, Johan (1971) A structural theory of imperialism. Journal of Peace Research 8(2): 81-117.

Garfinkel, Michelle R; Stelios Skaperdas \& Constantinos Syropoulos (2008) Globalization and domestic conflict. Journal of International Economics 76(2): 296-308.

Gartzke, Erik (2007) The capitalist peace. American Journal of Political Science 51(1): 166-191.

Gartzke, Erik \& Yonatan Lupu (2012) Trading on preconceptions: Why World War I was not a failure of economic interdependence. International Security 36(4): 115-150.

Gartzke, Erik; Quan Li \& Charles Boehmer (2001) Investing in the peace: Economic interdependence and international conflict. International Organization 55(2): 391-438.

Gelpi, Christopher F \& Joseph M Grieco (2008) Democracy, interdependence, and the sources of the liberal peace. Journal of Peace Research 45(1): 17-36.

Gleditsch, Nils Petter (2008) The liberal moment fifteen years on. International Studies Quarterly 52(4): 691-712.

Goenner, Cullen F (2010) From toys to warships: Interdependence and the effects of disaggregated trade on militarized disputes. Journal of Peace Research 41(5): 589-605.

Goenner, Cullen F (2011) Simultaneity between trade and conflict: Endogenous instruments of mass destruction. Conflict Management and Peace Science 28(5): 1-20.

Hartzell, Caroline A; Matthew Hoddie \& Mollie Bauer (2010) Economic liberalization via IMF structural adjustment: Sowing the seeds of civil war? International Organization 64(2): 339-356.

Hegre, Håvard; Ranveig Gissinger \& Nils Petter Gleditsch (2003) Globalization and internal conflict. In: Gerald Schneider, Katherine Barbieri \& Nils Petter Gleditsch (eds) Globalization and Armed Conflict. Lanham: Rowman \& Littlefield, 251-275.

Hegre, Håvard; John Oneal \& Bruce Russett (2010) Trade does promote peace: New simultaneous estimation of the reciprocal effects of trade and conflict. Journal of Peace Research 47(6): 763-774.

Hobsbawm, Eric J (1993) The Age of Extremes: The Short Twentieth Century, 1914-1991. London: Michael Joseph.

Keshk, Omar MG; Brian M Pollins \& Rafael Reuveny (2004) Trade still follows the flag: The primacy of politics in a simultaneous model of interdependence and armed conflict. Journal of Politics 66(4): 1155-1179.

King, Gary (2011) Ensuring the data rich future of the social sciences. Science 331(11): 719-721. 
Kinne, Brandon J (2012) Multilateral trade and militarized conflict: Centrality, openness, and asymmetry in the global trade network. Journal of Politics 74(1): 308-322.

Kramer, Alan (2007) Dynamic of Destruction: Culture and Mass Killing in the First World War. Oxford: Oxford University Press.

Magee, Christopher SP \& Tansa George Massoud (2011) Openness and internal conflict. Journal of Peace Research 48(1): 59-72.

Mansfield, Edward D \& Brian M Pollins (2003) Interdependence and conflict: An introduction. In: Edward D Mansfield \& Brian M Pollins (eds) Economic Interdependence and International Conflict: New Perspectives on an Enduring Debate. Ann Arbor, MI: University of Michigan Press, 1-28.

Maoz, Zeev (2009) The effects of strategic and economic interdependence on international conflict across levels of analysis. American Journal of Political Science 53(1): 223-240.

Martin, Philipe; Thierry Mayer \& Mathias Thoenig (2008) Civil war and international trade. Journal of the European Economic Association 6(3): 541-550.

Massey, Douglas S (2009) Globalization and inequality: Explaining American exceptionalism. European Sociological Review 25(1): 9-23.

McDonald, Patrick J (2009) The Invisible Hand of Peace: Capitalism, the War Machine, and International Relations Theory. Cambridge: Cambridge University Press.

Melitz, Mark J (2003) The impact of trade on intra-industry reallocations and aggregate industry productivity. Econometrica 71(6): 1695-1725.

Midtgård, Trude Mariane; Krishna Vadlamannati \& Indra de Soysa (2013) Does the IMF cause civil war? A comment. Review of International Organizations (in press). DOI: 10.1007/s11558-013-9167-z.

Morrow, James D (1999) How could trade affect conflict? Journal of Peace Research 36(4): 481-489.

Mousseau, Michael (2000) Market prosperity, democratic consolidation, and democratic peace. Journal of Conflict Resolution 44(4): 472-507.

Mousseau, Michael (2012) Capitalist development and civil war. International Studies Quarterly 56(3): 470-483.

Mousseau, Michael (2013) The democratic peace unraveled: It's the economy. International Studies Quarterly 57(1): 186-197.

Mousseau, Michael; Omer F Orsun \& Jameson Lee Ungerer (2013) Does the market-capitalist peace supersede the democratic peace? The evidence still says yes. In: Gerald Schneider \& Nils Petter Gleditsch (eds) Assessing the Capitalist Peace. Abingdon: Routledge, 127-136.

Mousseau, Michael; Omer F Orsun, Jameson Lee Ungerer \& Demet Yalcin Mousseau (2013) Capitalism and peace: It's Keynes, not Hayek. In: Gerald Schneider \& Nils Petter Gleditsch (eds) Assessing the Capitalist Peace. Abingdon: Routledge, 80-109.

Nieman, Mark D (2011) Shocks and turbulence: Globalization and the occurrence of civil war. International Interactions 37(3): 263-292.
Nye, Joseph S, Jr (1988) Neorealism and neoliberalism. World Politics 40(2): 235-251.

Olzak, Susan (2011) Does globalization breed ethnic discontent? Journal of Conflict Resolution 55(1): 3-32.

Oneal, John R \& Bruce Russett (1999) The Kantian peace: The pacific benefits of democracy, interdependence, and international organizations, 1885-1992. World Politics 52(1): 1-37.

Oneal, John R; Frances H Oneal, Zeev Maoz \& Bruce Russett (1996) The liberal peace: Interdependence, democracy, and international conflict, 1950-85. Journal of Peace Research 33(1): 11-28.

Østby, Gudrun (2008) Polarization, horizontal inequalities and civil conflict. Journal of Peace Research 45(2): 143162.

Poast, Paul (2010) (Mis)using dyadic data to analyze multilateral events. Political Analysis 18(4): 403-425.

Polachek, Solomon W (1980) Conflict and trade. Journal of Conflict Resolution 24(1): 55-78.

Polachek, Solomon \& Jun Xiang (2010) How opportunity costs decrease the probability of war in an incomplete information game. International Organization 64(1): 133-144.

Rosecrance, Richard (1986) The Rise of the Trading State: Commerce and Conquest in the Modern World. New York: Basic Books.

Ross, Michael L (2012) The Oil Curse. How Petroleum Wealth Shapes the Development of Nations. Princeton, NJ: Princeton University Press.

Russett, Bruce M (1967) International Regions and the International System: A Study in Political Ecology. Chicago, IL: Rand McNally.

Russett, Bruce \& John R Oneal (2001) Triangulating Peace: Democracy, Interdependence, and International Organizations. New York: WW Norton.

Sachs, Jeffrey D \& Andrew M Warner (1995) Economic reform and the process of global integration. Brookings Papers on Economic Activity 1: 1-95.

Sadeh, Tal (2013) The Euro's effect on trade. Unpublished paper, Tel Aviv University.

Sala-i-Martin, Xavier (2006) The world distribution of income: Falling poverty and ... convergence, period. Quarterly Journal of Economics 121(2): 351-397.

Scheve, Kenneth \& David Stasavage (2010) The conscription of wealth: Mass warfare and the demand for progressive taxation. International Organization 64(4): 529-561.

Schneider, Gerald (2010) Economics and conflict. In: Robert A Denemark (ed.) The International Studies Encyclopedia. Malden, MA/Oxford: Wiley-Blackwell, 1284-1300.

Schneider, Gerald (2013) Globalization and social transition. In: Edward Newman \& Karl DeRouen, Jr (eds) Routledge Handbook of Civil Wars. Abindgon: Routledge (in press).

Schneider, Gerald \& Günther G Schulze (2003) The domestic roots of commercial liberalism: A sector-specific approach. In: Gerald Schneider, Katherine Barbieri \& Nils Petter 
Gledisch (eds) Globalization and Armed Conflict. Lanham, MD: Rowman \& Littlefield, 103-122.

Schneider, Gerald \& Nils Petter Gleditsch (2010) The capitalist peace: The origins and prospects of a liberal idea. International Interaction 36(2): 107-114.

Schneider, Gerald \& Vera E Troeger (2006) War and the world economy: Stock market reactions to international conflicts. Journal of Conflict Resolution 50(5): 623-645.

Schrodt, Philip A (2012) Precedents, progress, and prospects in political event data. International Interactions 38(4): 546-569.

Schumpeter, Joseph A (1918/19) Zur soziologie der imperialismen [Sociology of imperialisms]. Archiv für Sozialwissenschaft und Sozialpolitik 46: 1-39, 275-310. English version in Richard Swedberg, ed. (1991) The Economics and Sociology of Capitalism. Princeton, NJ: Princeton University Press, 141-219.

Schweickart, David (2011) After Capitalism. Lanham, MD: Rowman \& Littlefield.

Simmons Beth A (2003) Pax mercatoria and the theory of the state. In: Edward D Mansfield \& Brian Pollins (eds) New Perspectives on Economic Exchange and Armed Conflict. Ann Arbor, MI: University of Michigan Press, 31-43.

Simmons Beth A \& Zachary Elkins (2004) The globalization of liberalization: Policy diffusion in the international political economy. American Political Science Review 98(1): 171-189.

Spilerman, Seymour (2009). How globalization has impacted labour: A review essay. European Sociological Review 25(1): 73-86.

Stiglitz, Joseph E (2000) Capital market liberalization, economic growth and instability. World Development 28(6): 1075-1086.
Stiglitz, Joseph E (2002) Globalization and its Discontents. London: Allen Lane.

Stiglitz, Joseph E (2004) Capital-market liberalization, globalization, and the IMF. Oxford Review of Economic Policy 20(1): 57-71.

Subramanian, Arvind \& Wei Shang-Jin (2007) The WTO promotes trade, strongly but unevenly. Journal of International Economics 72(1): 151-175.

Weede, Erich (1995) Economic policy and international security: Rent-seeking, free trade and democratic peace. European Journal of International Relations 1(4): 519-537.

Wallensteen, Peter (1973) Structure and War: On International Relations 1920-1968. Stockholm: Raben \& Sjögren.

Wiesehomeier, Nina; Gerald Schneider \& Constanze-Sophie Braun (2009) Die Vereinbarkeit des Unvereinbaren? Wirtschaft und Identität als gemeinsame Bürgerkriegsursachen [Reconciling the incompatible? Economy and identity as joint causes of civil war]. Politische Vierteljahresschrift Sonderheft 43: 445-470.

Williamson, Jeffrey G (2011) Trade and Poverty: When the Third World Fell Behind. Cambridge, MA: MIT Press.

Xiang, Jun; Xu Xiaohan \& George Keteku (2007) Power: The missing link in the trade-conflict relationship. Journal of Conflict Resolution 51(4): 646-663.

GERALD SCHNEIDER, b. 1962, Dr. phil. (University of Zürich, 1991); Professor of Political Science, International Relations Chair, University of Konstanz (1997- ); Executive Editor of European Union Politics and President of the European Political Science Association (2013-15). 